\title{
Hashing It Over: Green Governmentality and the Political Economy of Food
}

\author{
Timothy W. Luke
}

\section{The Starter Course: Food and Green Governmentality}

This analysis is a cautious provisional exploration of one aspect of the new green economy. At best, it serves as a prelude to more elaborate critiques of today's growing economic inequalities, and their close ties industrial food system and its ecology. The nexus of human food with ecological degradation has been a leitmotif in the contemporary American environmental movement since at least 1962 when Rachel Carson traced some of the detrimental effects of DDT contamination in North America's food chains. Consequently, efforts to trace the ties between "a vibrant food politics" that explores why "what we choose to eat" as well as how "the production, distribution, and consumption of food affords--as individuals, societies, and a species--both power and privilege over others" (Lavin, 2011) is vital for a more complex economic critique of the present. In probing the economies and cultures of industrial food production today, it seems clear "that an increased attention to political economy is the sine qua non for a revived cultural studies" (Smith, 2011: 6). As an exploratory exercise in ecology as critique and self-critique, this study digs into the political economy of food to unearth a handful of its economic inequalities and how environmental activism both can assail and assuage them.

In that spirit, this exploration also surveys a few of the deepening economic and social inequalities that local activists, community agriculture enthusiasts, and neighborhood revitalizers have opposed with a diverse array of policies and practices. By using food ecologies as the spearhead of broader social transformations, these social forces have sought to redirect the production, distribution, and consumption of food. Yet, this analysis also considers how some of today's well-intentioned interventions, which have been aimed at the reform of food policies, could appear to articulate contradictory policy assemblages embedded in the controlling logics of green governmentality (Luke, 1995).

In particular, one must reexamine the mixed record of purportedly alternative, communitarian or emancipatory practices, namely, those tied to attaining more economic autonomy and cultural authenticity in self-produced, locallydistributed and quickly-consumed foods from "locavorist" urban agriculture. Such food stocks are produced by a bevy of loosely organized initiatives from officially endorsed CSA (community supported agriculture) groups to semi-illegal "guerrilla gardening" circles. Often, these popular interventions seem radical, populist or anti-systemic. At the same time, one wonders if these developments can be a marker of how contemporary capitalist modernity's retrograde limits and contradictions oddly can manifest themselves in what are allegedly progressive practices? Indeed, the significance of such developments seems far more mixed and murky than the bright burnish their enthusiasts have given to them (Kennedy, 2011; and, Bane, 2012). Michael Pollan (2006: 10) is now famous for noting, "the way we eat represents our most profound engagement with the natural world," and then setting off in search of ideal examples of ethically self-sourced, cultivated, and/or foraged meals that actualize certain food experiences as authenticity. Something like greater "food justice" (Gottlieb and Joshi, 2010) can develop from such initiatives, but then so too might greater food injustice. While the supporters of heavily authenticated eating economies highlight the bright liberational opportunities for realizing greater nutritional health or personal freedom for all who engage in authentic food-getting activity (Permaculture Activist, 2011), is it just as plausible to see instances of locavore food 
politics as the darker necessities of an austerity intent upon coping with broader institutional systemic crises that already have begun (Homer-Dixon with Garrison, 2009)?

\section{| Out on the Ground: One Intriguing Intervention}

Following these lines of flight in the world economy, a recent news story comes from the Virginia Cooperative Extension (VCE) service as an instructive insight. In reviewing its report, one wonders if its accounts reveal a few of the operators of institutionalized domination, working to support, reinforce, and multiply each other in a blur of green good intentions that ensure how "society must be defended" (Foucault, 1997) today. Facing broken families, obese citizens, underemployed workers, and vacant land, the VCE news release recounts how Henrico County's Board of Supervisors recently approached the Extension Service to deal with high infant mortality, poor nutrition, and family stress in one district of the county. As the VCE horticulture agent in Henrico County observed, "we knew that if we improved the nutrition and physical activity of the people in that district, we might be able to make a difference. Encouraging people to grow their own fruits and vegetables would provide a physical activity that they could do together as a family and provide them with access to fresh and nutritious food" (http://www.vt.edu/ spotlight/impact/2011-08-15-local-food/henrico.html.)

Starting with two acres, VCE mobilized seven families to work 12 plots during 2008. In 2010, the acquisition of another near-by property allowed more families to join in this experiment, and now over 20 families are tilling 27 plots in 2011. While the VCE explicitly targets low-income families, anyone can join this community gardening campaign as long as they follow VCE's handbooks, take VCE classes, adhere to VCE rules regarding general safety, personal responsibility, and group activity, and then adopt VCE approaches to organic methods for the cultivation, preservation, and preparation of their family-grown produce. On the one hand, many people appear to be eating differently. And, on the other hand, their changed food practices are articulating a mode of green governmentality through this VCE program for "Gardens Growing Families," which is proving to be quite effective. The VCE horticultural agent reports " 77 percent of gardeners indicated that they saved money by growing their own fruits and vegetables in 2010. And 94 percent of the gardeners said their family diet improved as a result of the vegetables or fruit grown in their garden" (http:/ /www.vt.edu/spotlight/impact/2011-08-15-localfood/henrico.html.)

When they were surveyed by VCE experts, the Garden Grown Families indicated that they believed their members cooperated together better as domestic units, cultivated a stronger work ethic, and improved their daily diet, while keeping to a tighter household food budget. The willingness to waste money on the less fresh, less healthy, and less economical products of the fast food industry was sharply curtailed. And, apparently the importance of personal effort and economy became far more evident as moral tasks to the participants when they began tilling the earth.

The VCE concluded, such local urban agricultural initiatives should be embraced and expanded as important new policy practices that put "food on the table and bring families together." This recent effort is only one small experiment. Nevertheless, it proves instructive amidst today's deepening inequalities to the extent that the VCE approach to food as economy perhaps has begun, in turn, to test new tactics by which "society must be defended" by mobilizing, first, the underclass and then, next, other willing participants to re-socialize themselves as cultivators, consumers, and collaborators in a community garden.

Pollan has observed that eating is "an ecological act, and a political act, too. Though much has been done to obscure this simple fact, how and what we eat determines to a great extent the use we make of the world--and what is to become of it" (Pollan, 2006: 11). His criticism of omnivorous humans essentially pivots upon the industrial food chain's massive substitution for renewable carbohydrate energies drawn from plants, and then burned by animals and humans to sustain themselves on complex carbon molecules from photosynthesis, with new toxic and dirty nonrenewable hydrocarbon fossil fuels. That is, "industrial agriculture has supplanted a complete reliance on the sun for our calories with something new under the sun: a food chain that draws much of its energy from fossil fuels instead" (Pollan, 2006: 10). These fossil fueled modes of industrial agrarian life in America are the greatest expression of its population's excessive waste, or general affluenza, or quest for easy money to be spent unwisely (Berry, 2009).

While fossil fuel has generated agricultural abundance in the U.S.A. for America and the world, this newfound plenty is one of immense waste. Every acre of corn takes at least a barrel of oil to produce; each beef cow takes 
nearly a barrel of oil to grow, feed, and bring to market with each pound of beef usually taking 7 pounds of corn to grow; and, many fast food lunches for four (usually eaten in a car) take about 1.3 gallons of oil to produce (Pollan, 2006: 45-46, 83-84, 115, 117). Humans are indeed omnivores, but actually those at the top fifth or third of the world chain are, in some real sense, essentially monivorous. Their ultimate food source is oil, making them to a very real extent "petrovores."

Petrocomestibles, however, are the epitome of capital, energy, labor, and material waste. Hence, many of today's new food politicizers, like the VCE or guerrilla gardeners, make it their imperative to bring a new economy of food into being at least for some significant number of people. It is one that depetroleumizes, deruralizes, and perhaps even deindustrializes, the modern food chain by localizing, slowing, and de-diversifying the array of foods available to such omnivorous humans. Indeed, today's most spirited proponents for civic agrarianism see urban agriculture as having a long-term crisis mitigation utility. Consequently, they assert "one of the shortest routes from passive consumer to active food system designer is through the community garden" (Tracey, 2011: 9). With 48 million people ages 18 to 64 in the U.S.A. not working even one week a year in 2010, and 45 million in the same fix during 2009, the community garden perhaps is now part of the new social safety net (Tavernise, 2011b: A1). 15 percent of the entire population, and nearly 25 percent of all children live below the official poverty level (Doughtery, 2011: A4), so becoming "active food system designers" maybe one of the best legal options that many individuals have available to survive everyday life in contemporary America.

To attain this new food economy, however, all must twist down, and then slowly almost turn off, the petropower spigot. Are Henrico County's poor neighborhoods arguably one of its prefigurations? Visiting an organic farm in California, Pollan is shocked that "growing, chilling, washing, packaging, and transporting each box of organic salad to a plate on the East Coast takes more than 4,600 calories of fossil fuel energy, or 57 calories of fossil fuel energy for every calorie of food" (2006: 167). His amazed calculations capture the centrality of the industrial food chain's energy-intensitivity. Nonetheless, if communities move in disgusted awe from this level of wasted fossil fuel calories into a new food economy grounded on more locally-sourced, organism-powered, or personally-grown comestibles, then the world we make around, and out of our food must change radically by returning to small-scale, labor-intensive, and locally-based modes of cultivation.

With world demand for oil rising 25 billion barrels a year, and the American dollar becoming less desirable to price global oil purchases, and oil prices rising in real terms to perhaps $\$ 150$ a barrel (as they did briefly during 20082009 ) or maybe $\$ 200$ or $\$ 300$ a barrel in the near future, the U.S.A. as a whole will not be able to afford $\$ 8.00$ a gallon gasoline or $\$ 300$ a barrel crude. Of course, fracking oil and gas reserves captured in certain rock formations across the nation could slightly postpone these dire developments. Postponements, however, are not permanent solutions. Hence, many CSA activists believe "of necessity, Americans will return to a simple way of life....One way this can happen is by having massive unemployment in those sectors of the economy that do not generate exportable goods and services, such as residential construction and real estate. Unemployed people will use less gasoline and buy less stuff at Wal-Mart. Tradewill ultimately balance. The fact is that we can get by on a lot less than we have been" (Worth, 2010: 30).

A new kind of politics, then, is implied by reordering who does what, when, and how when there is a lowering of all fossil fuel caloric inputs into food caloric outputs. It is not shocking, as the VCE indicates, that people with lots of time, energy, and labor to spare will be brought first into the daily routines of "Green Grown Families," if there are no better economic alternatives. Still, without more due deliberation, these shifts undoubtedly could result in new more inequitable arrangements for pushing trends toward "degrowing" big industrial food chains as well as supercharging other smaller upscale postindustrial food markets around today's unequal class divides.

\section{Dilemmas in the Dirt: Omnivores or Petrovores}

Does the trope of omnivores "facing the dilemmas" of choosing carnivorousness, herbivorousness or at least less omnivorousness, as Pollan's writings assert, occlude a bigger structural imperative embedded in the industrial food chains? Modern American society's reliance upon a nonrenewable legacy resource drawn from 500 million years of fossilized solar energy in coal, gas, and oil deposits (Homer-Dixon with Garrison, 2009: 65) makes an organic salad from California available in Maryland at everyday low prices as petrovory extremely problematic. While coal and gas along with oil now constitute 85 to 90 percent of human energy use, it still is petroleum that drives much 
of today's industrial food chain (Crosby, 2006). Renewable sources of energy have increased during the past 150 years, but the typical global consumer on average uses the same amount of such energy--percentage-wise annually-as one did in 1850. Fossil fuel use, on the other hand, has risen eightfold per capita since 1850 (Homer-Dixon with Garrison, 2009: 66), so typifying this food economy and ecology as one rooted in oil-burning makes analytical sense.

The miracles of modern industrial agriculture rest upon "mining" rather "minding" the Earth's resources -- a depredation that has been clearly recognized by many critics for decades. Pollan and others in the new sustainable food movements of the twenty-first century are only rediscovering worries expressed by the Scott and Helen Nearing in the 1930s, Barry Commoner in the 1960s, or Wendell Berry in the 1980s. Despite decades of criticism, however, petrocomestibility has only grown more elaborate, excessive, and extreme. It is not clear that real change can come now, but many more people are considering it as a more viable option. In its bright promise phase, more locavory appears in the guise of ethical awareness, ecological concern or economical sensibility; but, in fact, its darker realities are very clear. As Pollan suggests, eating is a political act. And, a major element in the politics of this new eating assemblage is adapting large groups of once affluent, but now increasingly impoverished, people to irreversible climate change, worsening economic inequality, collapsing industrial economies, and eroding urban landscapes (Hacker and Pierce, 2010) by keeping them fixed in place as postconsumerist cultivators living in dying automobile suburbs or stressed big cities as their access to oil-burning globovore food ecologies closes.

A few individuals with serious financial means undoubtedly will continue to enjoy the bounty of many diverse and intensive food chains from their specialized niches in the widening two-tiered economy of the present (Vlasic, 2011); but, at the same time, many others will lose out. Food deserts already exist, and their emptiness is spreading. To combat food desertification, the increasingly superfluous or obsolete majorities of most industrial-era factory and farm workers shall be left by necessity and design to live, at least in part, more deeply in new deindustrialized, depetroleumized, deglobalized, denationalized, and demechanized food ecologies. These webs of economy are pushing them in the direction of "Gardens Growing Families," which are tactics to mobilize their labor time, animal energy, and personal property to feed themselves and their neighbors. Rather than advancing slow food, soft energy paths, and simple living as superior forms of human emancipation, as many of their original advocates have stressed during the last forty or fifty years of fossil fueled excess, are these alternative political economies being valorized in today's lingering Great Recession as sensible survival strategies for mitigating economic stagnation or adapting to technological decline as petropowered civilization becomes less sustainable? Arguably, yes. Food transfer payments are one of Washington's highest social welfare expenditures, and anything that can reduce them is welcome news in President Obama's second term

Of course, large-scale global economic disruptions cascade into almost all urban neighborhoods and suburban tracts, and they can cause what their residents experience as "the city's social issues of homelessness, addiction, prostitution, and crime" (Tracey, 2011: 10). When a city lot or a few abandoned homes' backyards are turned into gardens for community supported agriculture where the local residents will do much of the daily work, a very convenient relation of people to things, or people without things to their environment, can come into force. Tracey, for example, comments upon the residents of Vancouver's Downtown Eastside:

Some did not have homes themselves, which may be why the site turned into a farm that resembled an outdoor living room. All kinds of neighborhood people would drop in. Nurses would visit on breaks from the only legal facility in North America where addicts can use heroin under medical supervision. Sometimes six-trade workers would stroll in to pick up a few raspberries off the vine, perhaps the only fresh organic food they would eat that day. Others would come in just to sit for 20 minutes away from the chaos of the street. Urban agriculture is all about the food, but it can also be about much more than that (Tracey, 2011:9-10).

CSAs plainly are about much more than the food; they are, as this activist's idyll reveals, about agriculture supporting community. To grow food where people live is significant; but, keeping people where they live no matter how destitute, getting them engaged in productive, rewarding, albeit unpaid, labor to promote healthy survival, and organizing more secure, stable, and safe neighborhoods within the limits of this alternative agrarian commonwealth are decisively useful tactics to cope with the contemporary crisis.

Rather than perhaps creating a true cultural advance through collective social and economic transformation to prefigure another better form of modernity, as their original deep green advocates asked, are these reformist locavores more often than not also picking piecemeal over earlier green radical designs for survivalistic tactics to mitigate the unintended demodernizing consequences of neoliberal financialization? Without justifying what have been, and are, fixed relations of global inequality the collapse of once wealthy national economies (as well as their 
more prosperous and stable core cities, neighborhoods, and towns) seems to be reducing many locales to a more peripheralized status plagued by huge brownfields, dead zones or obsolescent areas.

Out of such spaces, the inhabitants of once prosperous states face life up against growing food deserts, service cutbacks, job deserts, security deficits, housing losses, and population migrations as spatiality itself remediates the full spectrum of complex economic and social decline (Brenner, 2002). Too many accounts of "food deserts" focus only on inner-city neighborhoods (Chittum, 2011). In fact, the vast expanses of petropowered agriculture have monoculturalized rural America through petrovory to the point that many farmers also live on monivorous food deserts even more dire than those of inner-city consumers.

Space, as Lefebvre (1991) argues, is more than the naturalized expanses, surfaces, and volumes of ordinary physical matter. It is, more importantly, the material articulation and activation of social relations. The relentless drive to conquer uninhabited, or only sparsely settled, lands and waters in the grand rush to attain economic, industrial, social, and urban development during the Industrial Revolution from 1720s through the 1970s by the West has been called "development." Its waves of modernization occupied and ordered space with the social interactions of modern urbanization, organization, and administration of a commercial world system that reified multiple spatialities in the cruel fusion of statist empires and business emporia, which one might designate as the creatively fused emporium of capital and power. Working around the classic capitalist antinomies of capital/labor, urban/rural, industry/ agriculture, city/country, settlement/wilderness, the industrial food chain is one of modernity's most reified spatial articulations (Pollan, 2008). In many ways, petropowered agricultural path dependencies developed out of centuries of struggle over land, labor and capital after World War I. In some places, the apparatus of industrial agriculture will still persist for the few, but its relations of organization, order, and operation plainly have been splintering for the many since the late 1990s and early 2000s (Marazzi, 2011).

When seen in this light, today's diverse celebrations of agro-ecology, green cities, agro-urbanism or community agriculture on a local, small footprint, and frugal scale, which have worked in a variety of once so-called Third or Fourth World settings, are a somewhat mixed blessing. A "plant's eye view of the world" (Pollan, 2002) is only in part one in which a desire for basic botanical skills boosts nutrition, life chances and social capital stocks as much or more than machinic aplomb (Pollan, 2002). The spreading sprawl of these underdeveloped sites also is renowned for its destitution. Other sociological studies fretting about the Earth's future, identify it as the definitive marker of a "planet of slums" (Davis, 2008).

Poorer people can be prepared and equipped to till nearby brownfields to feed themselves and their families. Are what once might have been Liberty Gardens, Victory Gardens or Whip Inflation Now Gardens only unfree patches, defeated plots or deflationary diggings? Of course, each one "draws from Sun and Earth" (Morrison, 2011: 4-5), but with an array of immobile, underpaid and unfree labor practices adopted out of necessity along the way. In some sense, Pollanesque food politics are a new ethical consumerism (Lavin, 2009); but, in other more insidious developments, these clean, lean, or green styles of being also can express a highly re-engineered postconsumerist politics for underemployed cultivators of bankrupt businesses' green space, foreclosed upon homes' front lawns or failed subdivisions' street medians.

\section{Overcooked Economies: Adaptations and Mitigations}

The contemporary need for new environmental practices, like sustainable community agriculture, emerges from a specific set of conditions. Those particularities can best be mapped, first, in the recent crises of the Great Recession, and, second, in the systemic decay of economic and social equality in the U.S.A. since the 1970s. Both of these tendencies deserve some extended discussion. An overview of how long-term trends towards economic collapse set the stage for new adaptation and mitigation strategies tied to new food ecologies, therefore, is worth mapping.

A recent report from the Pew Research Center confirms the worrisome significance of these broader trends toward economic inequality by reassessing American household income and wealth. During the recent housing crisis, more and more regions in the U.S.A. seem to be sliding off toward the "planet of slums" after decades of neoliberal policies of dispossession. In 2005, the median household net worth of all American households was $\$ 198,894$. For white households, this figure stood at $\$ 134,992$, black households stood at $\$ 12,124$; Hispanics at $\$ 18,259$; and Asians at $\$ 168,103$. Yet, after the Great Recession, the 2009 net household worth figures were severely worse. All 
households' net worth had fallen during four years to the figure of $\$ 70,000$; white households at $\$ 113,149$; black households at \$5,677; Hispanics at \$6,235, and Asians at \$78,066 (Tavernise, 2011a: A1). These still burning losses have now led to the greatest wealth disparities in the U.S.A. since 25 years ago. Indeed, the median worth of white households is 20 times greater than blacks and 18 times greater than Hispanics (Kochar, Fry, and Taylor, 2011: 1). Hispanics are 16 percent and blacks are 12 percent of the U.S. population, but one-third ( 35 percent) of all black and Hispanic households (31 percent) had a zero or negative net worth in 2009 as opposed to only 11 percent of white households (Kochar, Fry and Taylor, 2009: 2). While things have improved moderately since 2012, the positive trend lines here are the weakest since 1945.

Over the past generation, one out of every three Americans who grew up in a middle class household has dropped back into the lower classes, and this finding is drawn from data only from 1979 to 2006 . Another Pew Charitable Trust study examined teenagers in 1979 that were between 39 and 44 in 2004 and 2006. Remaining in the middle class was marked by steady income in a range between the 30th and 70th deciles of income distribution, or living, for example, in a family of four with $\$ 32,900$ to $\$ 64,000$ of income annually in 2010 dollars (Roanoke Times, 2011a: A8). One out of three people experienced downward mobility in the U.S.A., which was marked by falling below the 30th decile of income, or falling 20 percentiles or more than their parent's household income or earning annually 20 percent or more less than their parents (Roanoke Times, 2011a: A8).

Major Fortune 50 firms in the U.S.A have noticed this deterioration in middle class living standards. Procter \& Gamble, for instance, in 2011 launched its first dish soap since 1973 for the downmarket "bargain" niche. Because it has products in 98 percent of all U.S. households, and it wants to keep them there, P\&G is tracking how the middle class -- or all households in the $\$ 50,000$ to $\$ 140,000$ in annual income range - is shrinking overall, while its members endure constant distress every month. P\&G's marketing experts have determined the median income in the U.S.A. in 2009 was lower after inflation than in 1998 (Byron, 2011: A16). The big dips in family income came in the 1970s, the early 1990s, and since 2006, which all have left the U.S.A. with a Gini index of 0.468. This coefficient indicates a 20 percent increase in income inequality in the U.S.A. since the end of the Cold War, leaving the United States with about the same Gini index for overall social inequality as Mexico or the Philippines (Byron, 2011: A16). Although it is not a welcome development for $P \& G$ executives, they recognize their long post-World War II run of successfully selling more, and gradually more expensive, household products to middle class market segments is ending.

To survive in the U.S.A., the company now targets consumers with systemically "falling" or "stagnating" incomes. As its vice-president for consumer marketing in North America notes, "this has been the most humbling aspect of our jobs. The numbers of middle America have been shrinking because people have been getting hurt so badly economically that they've been falling into lower income" (Byron, 2011: A16). Similarly, Federal Reserve records on household wealth indicate that Americans held about $\$ 6.1$ trillion in home equity in March 2011 . That figure was only half the 2006 level; and, all households' net assets grew only 2.4 percent from 2001 to 2007, only to tumble over 26 percent from 2007 to 2009 (Byron, 2011: A16).

Still, at the other higher end of the income distribution, whites in the top 10 percent of all such households saw their share of wealth increase from 46 percent in 2005 to 51 percent in 2009. Among Hispanics, this disparity is even greater as this figure rose from 56 percent in 2005 to 72 percent in 2009 (Kochar, Fry, and Taylor, 2011: 8). For 90 percent of American households, however, falling net worth, increasing amounts of free time, and the wasting opportunity of unused land in many cities and towns all combine as an opportune conjuncture to adapt many communities to these systemic crises by going all green out in the garden.

Petrovorous living obviously reshaped urban space, and this shift in the overall social context is crucial for understanding these food politics. In 1920, about 50 percent of the U.S. population lived in rural areas on a farm or ranch, and only seven percent of the nation's population lived in the suburbs. By 1950, after waves of automobility, two-thirds of Americans lived in cities or suburbs, and this figure hit 75 percent by 1970 as suburban populations eclipsed the number of inner-city residents (Florida, 2010: 35). For example, the "Motor City," or Detroit, expanded in area from 40 square miles in 1910 to 139 square miles in 1950 as its boundaries filled with workers and factories making all of the automotive apparatuses of petropowered prosperity (Florida, 2010: 34).

Yet, as the percentage of its industrial workforce fell from over 39 percent in 1951 to less than 19 percent of total population in 2010, Detroit crashed (Florida, 2010: 72). It has devolved into a vast capital, food, jobs, and technology desert. A million people left the city from 1950 to 2000; and, by 2009, 44,000 of its 65,000 homes that were in foreclosure were vacant, the unemployment rate was officially near 30 percent; and, 62,000 vacant lots or abandoned properties littered its landscapes (Florida, 2010: 72-74). Just the vacant land in Detroit amounts to an area almost equal in size to Boston, but Detroit still is the eleventh largest metropolitan region in the nation. It is, 
however, also full of many underemployed, less skilled, and dispossessed people. Now a test-case for "the shrinking city" (Lanks, 2006), Detroit is bulldozing down many of its vacant abandoned buildings. In turn, "acre upon acre of once useless vacant lots are being turned into vibrant urban farms" (Florida, 2010: 80). Such recultivated lands are, in turn, now occupied differently. Working the soil there is more typically depetroleumized, highly localized, and essentially deindustrialized as it pulls underemployed residents into a new agrarianism amidst industrial ruination. By substituting bigger amounts of time spent on small plots to grow food for hours of paid labor to manufacture industrial goods or provide complex services in big lots for collective benefit, the larger social and spatial relations of the population are experiencing and expressing major changes spatially.

Coevolving with these dismal realities of structural economic stagnation, one finds strangely cheerful hopes for "the third sector" of non-governmental organizations tied to urban agro-ecology. The belief is that they can rescue most people trapped in essentially hopeless conditions of economic collapse now manifest in these complicated spatial deformations. Urban agriculture, because it is not unlike the leisure activities of home gardening, is an easy sell, because it promises people better food, greater health, household improvement, ecological virtue or food security. Some will be saved, but can everyone improve their lot by community gardening?

Left underemployed, facing foreclosure, and needing to survive, people must look to their neighborhoods for solutions. Frequently, the houses there have some spare outside square footage and/or neighborhoods of these homes have vacant lots of sufficient size to make cultivating the Earth a viable proposition for cash-starved, if not truly undernourished, homeowners and tenants. Returning to the private plot, community garden or city lot to grow food is not a grand vision of an ever-more powerful modern society; but, these options can put food on the table that otherwise would not be there. Moreover, some cities now pay people with cash internships, minimum wage jobs or monetary incentives to adapt to economic stagnation through such microscale reagrarianization schemes.

Tracey suggests with regard to community gardens that they are local sites for normative engagement, but they also serve as points of organized normalization. That is,

A community garden is not just about vegetables. It can be a farm, a playground, a school, a temple, a gym, a stage, a refuge, a wildlife habitat, and more - all on the same day. At best, it derives its strength from and serves as a model for the community around it. Community gardens teach and celebrate values we cherish, including cooperation, volunteering, appreciation for diversity, and ecological awareness (Tracey, 2011:9).

Certainly, these virtues are worth preserving. With their preservation and the level of home foreclosures in 2011 exceeding 2010's record levels (Roanoke Times, 2011B: A8), one also sees strategies for protecting housing stock, bank capital, and private equity simply by people cooperating to feed each other beyond the conventional cash nexus.

\section{In a Stew: Eating as Authenticity or Austerity}

Again, the purpose of this preliminary study is to question cautiously the new politics of food in an era of considerable scarcity. Celebrants of the third sector, like Rifkin (2000) see such efforts to enhance the everyday economies of food as the best path out of "a commodified future in which all of life becomes a series of paid for performances, entertainments, and fantasies" and into an alternative green order with "emphases on connectivity, embeddedness, and relatedness. . . punctuated by a newfound sense of oneness and participation with others" (Rifkin, 2000: 212). Since it is not clear that the choices before the denizens of the planet's degraded urban sprawl are this certain, one must worry about why such fabulations for authenticity and food are also being presented to the underemployed, underpaid or even unemployed residents of areas that once were the so-called First World (Pollan, 2008).

As Virginia's Cooperative Extension service teaches, using food to anchor a new moral, political, and urban economy is indeed an exciting new recipe for enforcing social order. And, it points toward a two-tiered economy anchored by two unequal poles. One smaller tier will have high-paying secure careers, and the other much larger tier will feature mostly low pay/no pay unstable jobs (Vlasic, 2011; and, Rampell, 2011). For those less affluent citizens with a more hunter-gatherer disposition than an agrarian one, it is possible for those in the declining tiers of fixed, fallen, or fractionalized incomes to forage successfully on already in place urban landscapes, plots of random wild growth or just what appear to be weeds.

Kaplan, for example, notes, "in my small city, fruit literally hangs off of the trees and onto the streets. Some 
people harvest their backyard trees, but many people let the fruit fall and rot....foraging and gleaning are ways to eat local, save money, and practice our resourceful relation to place" (2011: 38). Noting many people have fruit trees; but, with no time for or interest in harvesting their crop, the enterprising forager can pick that fruit, leave a good measure on the owners' porches, and glean a surplus. Tons of food that would otherwise go to waste thereby becomes, once again, agriculture supporting community.

Similarly, civic agrarians point out how edible plants on public property can be mapped for personal and group foraging sessions. Such produce certainly will be wasted unless it is gleaned, so new urban agrarians would do well to identity, inventory, and then intercept this usufruct lest it go to waste. Gathering such crops is important, whether they are found on private property or public lands, to manage "food insecurity" inasmuch as foods "which otherwise would have gone to waste and rotted on people's lawns, was foraged and distributed to people who need it" (Kaplan, 2011: 38). The truly inventive new urban agrarian also can exploit the never obliterated biodiversity of naturally occurring perennial plants, or "weeds," that grow almost anywhere all the time. Knowing what parts are edible, where weeds will (or will not) get sprayed with herbicides as well as if they grow on private property is important. Yet, once those facts have been determined, foraging wild and weedy food stocks, from blackberries, burdock, chickweed, chicory, dandelion to mint, mustard, nasturtium, raspberries, sorrel, "is a most essential and beautiful skill to cultivate however you choose to practice it" (Kaplan, 2011: 39).

At the other end of the class continuum, however, property developers are recalibrating suburbia's designs for a shrinking top tier with good solid incomes. That is, "in a movement propelled by environmental concern, nostalgia for a simpler life and a dollop of marketing savvy, developers are increasingly laying out their cul-de-sacs around organic farms, cattle ranches, vineyards and other agricultural ventures" (Simon, 2011: R3). Edible landscaping, community orchards, along with zoning in cattle ranchettes, organic farms or boutique vineyards instead of strip malls, 24 hour minimarkets or tennis courts, are key ingredients of this new twist in mobilizing food as economy. To sell up-market suburban homes, the key amenity no longer are golf greens beyond the rear fence--it is salad greens in the backyard (Simon, 2011: R3).

These ideas weakly echo the aesthetics and economics of William Morris or Paul Goodman as their proponents anchor new conceptions for the townscape in visions of what Quint Redmond "calls "agriburbia," where suburbs aren't just built around a farm; they support food production at every turn” (Simon, 2011: R3). Where the underclass is left to forage from the lawns of the remaining affluent, inner city, home-owner; Redmond's design would plant almond, apple or avocado trees along all the agriburbia's streets. He would embed kale, corn or grains in golf course roughs. He will seed shrubbery beds with cabbage, carrots or currants, and edge lawns when they are necessary with chives or herbs (Simon, 2011: R3). Some in the up-market demographic may remain disinterested in this potential, but such new homes with their solar panels, super insulation, or embedded efficiencies also could spark other agriburban economies. "Mr. Redmond maintains," for those buyers seeking CSA-oriented attractions, "that many homeowners could earn half their mortgage payment by converting lawns into gardens and selling the bounty to restaurants or at farmer's markets. "Organic basil is like growing gold," he says. "You can net \$26,000 an acre"” (Simon, 2011: R3)

Globalization in its financialized neoliberal forms today is devalorizing key links in world commodity chains. This move is leaving some populations, regions, and settlements behind with no reliable source of continued growth, while preserving the energy-intensive traditional order for the up-scale end of the class hierarchy. In various households and neighborhoods along within certain towns and cities, alternatives for the maintenance of everyday life must be found--even if it leads to towards gradual deindustrialization, demechanization, and depetroleumization where foraging for free weeds or waste fruit is cast as a beautiful essential skill for liberation.

Community agriculture is a plausible response for people living in "food deserts," or low-income census tracts where a major fraction of the population is a mile away from its nearest supermarket in an urban setting or 10 miles away in a rural area, but it is crucial to see how and why accessible food-buying outlets deserted them. Low-income spaces indicate that there also are job deficits, housing degradation, income deserts, health deterioration, and skill declines sweeping across major concentrations of these same populations. The increasing degree of precarious living in all these registers reveals a new hollowed-out spatiality. Pushing this initiative is an intervention in favor of building a material alternative in which the dispossessed "build real wealth, increase food and energy security, reduce the need for income, create a home-based livelihood" (Permaculture Activist, 2011: inside front cover). The great cost and scarcity of oil already is tracing its constricting effects in such urban-industrial desertification (Ruppert, 2009). The waning of public goods and services is both mystified and made obvious by the mapping of food deserts. One must ask if the state is left only to go about mapping its food deserts, then what can it do about such economic 
desertification? Apparently, Proctor \& Gamble will identify these zip codes, track them as they become more like Mexico or the Philippines, and then develop more "bargain" downmarket goods to sell their residents.

Green critiques of modern industrial society have had highly progressive agro-ecological elements at their strategic core for decades as the potentially liberating basis for new cultural alternatives. Whether it is home-based solar power, collective neighborhood gardens or autonomous "off-the-grid” homes, like New Mexico's "Earth Ship" houses, once revolutionary designs to reorder everyday life in Fordist or post-Fordist urban industrial economies from the 1960s through the 1990s, have been essentially ignored. Yet, after being neglected for all this time, they are being (re)discovered as remediations of green governmentality (Luke, 1997). As they are discovered, bits and pieces of them are also repurposed as adaptive interventions for coping minimally with the aftermath of the same excessive patterns of helter-skelter urban industrialization at the center of those same green critiques. Rather than grounding some major transformational experiment for more emancipatory human existences, green populist agro-ecologies are being hashed over for measured expedients needed to adapt to economic decline and ecological degradation, which have been engineered by cognitive capitalism to aid the reproduction of plenty for the few and destitution in the dirt for the many?

Eating now is clearly, and even more ironically, a very political act. Warm green mythologies about getting back to the garden will have a hard time legitimating food authenticity alone as the path to a truly progressive future. Too many serious questions remain unanswered, because eating as authenticity can cloak hard new command, control, and communication campaigns for enforcing more austerity in the regimen of green governmentality. Is this new green economics being imposed in the ruins to sustain spirit of a society that must be defended, but only after it has been roundly defrauded?

\section{References}

*The initial efforts to articulate this argument were made at the Conference on "Ecological Inequalities \& Interventions: Contemporary Environmental Practices," George Mason University, September 22-23, 2011, and the annual meeting of the Western Political Science Association, Portland, OR, March 22-24, 2012.

Bane, Peter. 2012. The Permaculture Handbook. Bloomington, IN: Permaculture Activist.

Berry, Wendell. 2009. Bringing it to the Table: On Farming and Food. Berkeley, CA: Counterpoint.

Brenner, Robert. 2002. The Boom and the Bubble: The U.S. in the World Economy. New York: Verso.

Byron, Ellen. 2011. "As Middle Class Shrinks, P\&G Aims High and Low," Wall Street Journal (September 12): A1, A16.

Chittum, Matt. 2011. "Food Deserts," Roanoke Times (July 24): $1,12-13$.

Crosby, Alfred W. 2006. Children of the Sun: A History of Humanity's Unappeasable Appetite for Energy. New York: Norton.

Davis, Mike. 2008. Planet of Slums. London: Verso.

Doughtery, Connor. 2011. "Income Slides to 1996 Levels," Wall Street Journal (September 14): A1, A4.
Florida, Richard. 2010. The Great Reset: How the Post-Crash Economy Will Change the Way We Live and Work. New York: Harper Collins.

Foucault, Michel. 1997. "Society Must be Defended." New York: Picador.

Gottlieb, Robert and Anupama Joshi, eds. 2010. Food Justice. Cambridge, MA: MIT Press.

Hacker, Jacob S. and Paul Pierson. 2010. Winner-Take-All Politics: How Washington Made the Rich Richer--And Turned Its Back on the Middle Class. New York: Simon \& Schuster.

Homer-Dixon, Thomas with Nick Garrison, eds. 2009. Carbon Shift: How Peak Oil and the Climate Crisis Will Change Canada (and Our Lives). Toronto: Random House of Canada.

Kaplan, Rachel. 2011. "Foods from the Wilds of the City," Permaculture Activist, 81 (August): 38-39.

Kennedy, David. 2011.21st Century Greens: Leaf Vegetables in Nutrition and Sustainable Agriculture. Berea, KY: Leave for Life.

Kochar, Rakesh, Fry, Richard, and Taylor, Paul. 2011. "Wealth: Gaps Rise to Record Highs Between Whites, Blacks, Hispanics: Twenty-to-One," Pew Social \& Demographic Trends: Pew Research Center <http://pewsocialtrends. org/2011/07/26/housing-bubble-subprime-mortgageshispanics-blacks-household-wealth-disparity>. 
Lanks, Belinda. 2006. "The Incredible Shrinking City," Metropolis Magazine (April 17) < http://www.metropolismag. com/story/20060417/the-incredible-shrinking-city $>$.

Lavin, Chad. 2011. "The Vegetarian Lesson," The Chronicle Review (August 14). <http://chronicle.com/article/ the-vegetarian-lesson/128562/>.

Lavin, Chad. 2009. "The Year of Eating Politically, Theory \& Event, 12 no. $2<<$ http://muse.jhu.edu/journals/theory_and_ event/v012/12.2.lavin.html $>$.

Lefebvre, Henri. 1991. The Production of Space. London: Blackwell.

Luke, Timothy W. 1997. Ecocritique: Contesting the Politics of Nature, Economy and Culture. Minneapolis: University of Minnesota Press.

Luke, Timothy W. 1995. "On Environmentality: Geo-Power and Eco-Knowledge in the Discourses of Contemporary Environmentalism," Cultural Critique, 31 (Autumn): 57-81.

Marazzi, Christian. 2011. The Violence of Financial Capitalism, new edition. New York: Semiotext(e).

Morrison, Shawna. 2011. "Drawing from Sun and Earth," Roanoke Times: NRV Current (July 26): 4-5.

Permaculture Activist. 2011. 81 (August): 1-64.

Pollan, Michael. 2008. Food Rules: An Eater's Manual. New York: Penguin Press.

Pollan, Michael. 2006. The Omnivore's Dilemma: A Natural History of Four Meals. New York: Penguin Press.

Pollan, Michael. 2002. The Botany of Desire: A Plant's Eye View of the World. New York: Random House.

Rampell, Catherine. 2011. "At Well-Paying Firms, a Low-Paid Corner," New York Times (May 23): A1.
Rifkin, Jeremy. 2000. The Age of Access: The New Culture of Hypercapitalism, Where All Life is a Paid-For Experience. Boston: Putnam.

Roanoke Times. 2011a. "Study: Many Americans Fall Out of Middle Class," (September 7): A8.

Roanoke Times. 2011b. "2011 to Top 2010 Record of 1 Million Home Forecloses” (January 14): A8.

Ruppert, Michael C. 2009. Confronting Collapse: The Crisis of Energy and Money in a Post Peak Oil World. White River Junction, VT: Chelsea Press.

Simon, Stephanie. 2011. "An Apple Tree Grows in Suburbia," Wall Street Journal (September 12): R3.

Smith, Paul, ed. 2006. "Introduction," The Renewal of Cultural Studies. Philadelphia: Temple University Press. 1-8

Tavernise, Sabrina. 2011a. "Recession Study Finds Hispanics Hit the Hardest," New York Times (July 26): A1.

Tavernise, Sabrina. 2011b. "Soaring Poverty Casts Spotlight on 'Lost Decade," New York Times (September 14): A1.

The Economist. 2006. "Special Report: Inequality in America," The Economist (June 17): 28-30.

Tracey, David. 2011. "Urban Agriculture - Depaving Paradise," Permaculture Activist, 81 (August): 9-13.

Vlasic, Bill. 2011. "Detroit Sets Its Future on Two Tier Wages," New York Times (September 13): A1.

Worth, Kenneth D. 2010. Peak Oil and the Second Great Depression (2010-2030). Denver: Outskirts Press. 